\title{
Suppression of Oxyfluorfen Activity and Protoporphyrin IX Accumulation in Intact Cucumber Plants by Tetrapyrrole Synthesis Inhibitors*
}

\author{
Hiroshi Matsumoto** and Kozo Ishizuka**
}

\begin{abstract}
Effect of tetrapyrrole biosynthesis inhibitors on herbicidal activity of oxyfluorfen [2chloro-1(3-ethoxy-4-nitrophenoxy)-4-trifluoromethylbenzene] and protoporphyrin IX accumulation was determined in intact cucumber seedlings. Oxyfluorfen induced rapid light dependent bleaching and desiccation in the plant. The tetrapyrrole biosynthesis inhibitors, gabaculine and 4,6dioxoheptanic acid, strongly suppressed oxyfluorfen activity when the roots were treated with these chemicals for $15 \mathrm{hr}$ prior to the herbicide treatment to the shoots. A large accumulation of protoporphyrin IX occurred in oxyfluorfen-treated cotyledons in advance of the appearance of herbicidal symptoms. The inhibitors also reduced protoporphyrin IX accumulation and the pattern of reduction was very similar to that of herbicidal activity. These data indicate that protoporphyrin IX plays a critical role in the mode of action of oxyfluorfen in intact cucumber plants.
\end{abstract}

Key words : oxyfluorfen, protoporphyrin IX, gabaculine, 4,6-dioxoheptanoic acid, mode of action

* This work was presented at the 30th Annual Meeting of the Weed Science Society, Japan (1991).

** Institute of Applied Biochemistry, University of Tsukuba, Tsukuba, Ibaraki 305, Japan.

Abbreviations: PPIX, protoporphyrin IX ; Protogen, protoporphyrinogen; Protox, protoporphyrinogen oxidase; DHA, 4,6-dioxoheptanoic acid; ALA, $\delta$ aminolevulinic acid

(Received February 17, 1992)

\section{Introduction}

It is well demonstrated that photobleaching herbicides such as diphenyl ethers, cyclic imides and oxadiazoles cause protoporphyrin IX (PPIX) accumulation in leaf disks or cultured cells of many plant species ${ }^{1,2,6,15 \sim 17,20,25)}$. Accumulation of PPIX in plant tissues begins immediately after the herbicide treatment in the light. Since strong correlation has been found between the amount of PPIX accumulated in response to the herbicide treatment and the amounts of ensuing herbicidal demage $^{1,2,20,24)}$, PPIX is considered to be the responsible compound for the action of photobleaching herbicides. PPIX is known to be a generator of singlet oxygen through photodynamic action ${ }^{4,7,9)}$. The toxic oxygen species is thought to induce peroxidative degradation of plant membranes which also has been amply demonstrated ${ }^{5,12,14,23)}$.

The accumulation of PPIX is caused by inhibition of protoporphyrinogen oxidase (Protox) that converts protoporphyrinogen (Protogen) to PPIX, and by the subsequent autooxidation of Protogen to PPIX ${ }^{10,18,19,26)}$ in plant cells. Although the molecular target of the action of the herbicides appears to have been discovered, there is less published work on the relationship between PPIX accumulation and the herbicidal activity in intact plants. Matsumoto and Duke ${ }^{20)}$ studied the effect of acifluorfen-methyl on porphyrin accumulation in an aquatic higher plant, Lemna paucicostata. They found that PPIX alone accumulated to 
significantly high levels and that the amount correlated well with phytotoxic activity. There has not, however, been a study of porphyrin accumulation by photobleaching herbicides and their herbicidal activity in other intact higher plants.

Several inhibitors of porphyrin synthesis pathway such as gabaculine and 4,6-dioxoheptanoic acid (DHA) have been used to demonstrate the involvement of accumulated PPIX for the action of photobleaching herbicides. Great reductions of the herbicidal activity in inhibitor-treated excised tissues or cultured cells have been reported $^{15 \sim 17,25)}$. The objectives of the study were to determine effect of the porphyrin synthesis inhibitors on herbicidal activity of a diphenyl ether herbicide oxyfluorfen [2-chloro-1(3-ethoxy4-nitrophenoxy)-4-trifluoromethylbenzene] and on PPIX accumulation caused by the herbicide in intact cucumber plants.

\section{Meterials and Methods}

\section{Plant materials and treatment with chemicals}

Cucumber (Cucumis sativus L. [cv. Shimoshirazu-jibai]) seeds were planted in flats in vermiculite and watered with distilled water or onetenth strength of Hoagland solution. Plants were grown in a growth chamber with $25 / 20^{\circ} \mathrm{C}$, day $(12 \mathrm{hr}) /$ night for 7 days under $150 \mu \mathrm{E} / \mathrm{m}^{2} / \mathrm{s}$ PAR. They were then transferred to a nutrient solution culture. A day after transfer to the solution, roots of the plants were soaked in gabaculine or DHA solution for $15 \mathrm{hr}$ in darkness. Shoots were subsequently soaked in $1 \mu \mathrm{M}$ of oxyfluorfen solution for $1.5 \mathrm{hr}$, then washed with distilled water and immediately exposed to the light.

\section{Measurement of herbicidal damage}

After 6-hr exposure to the light, one cotyledon of the plants was excised from shoots and the cut end was covered with vaseline. The excised cotyledon was placed adaxial surface down in a polystyrene petri dish containing $10 \mathrm{ml}$ of distilled, deionized water. The dishes were then shaken slowly for $1 \mathrm{hr}$ in darkness. Electrolyte leakage into the water from the cotyledon was determined with a conductivity meter. The other cotyledons were excised after 8 - $\mathrm{hr}$ light exposure and their fresh and dry (oven-dried for $24 \mathrm{hr}$ at $90^{\circ} \mathrm{C}$ ) weights were determined.

\section{PPIX assay}

Two cotyledons from one plant were homogenized with methanol/0.1 N $\mathrm{NH}_{4} \mathrm{OH}(9 / 1, \mathrm{v} / \mathrm{v})$ under a dim, green light source. PPIX in the extracts was determined by HPLC with a fluorescence detector (Ex $400 \mathrm{~nm}, \mathrm{Em} 630 \mathrm{~nm}$ ) as described elsewhere ${ }^{20}$.

\section{Results}

\section{Effect of tetrapyrrole synthesis inhibitors on herbicidal activity of oxyfluorfen}

Shoots of intact cucumber plants were treated with oxyfluorfen for $1.5 \mathrm{hr}$ in darkness; then the plants were exposed to light. Wilting and bleaching of the cotyledons were initiated by the herbicide after $4^{-}$and 6 -hr of light exposure,

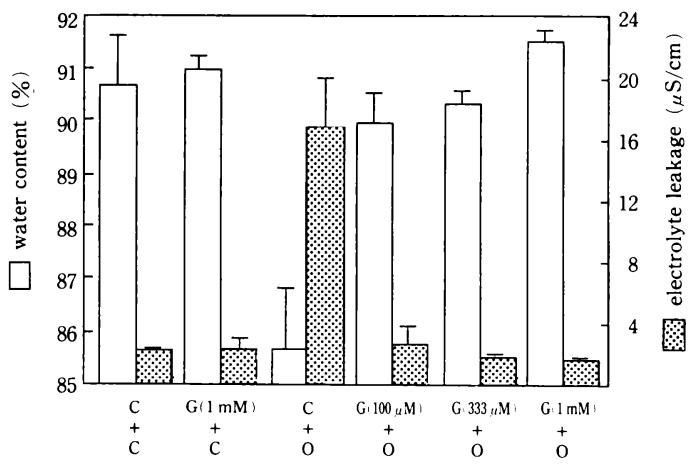

Fig. 1. Effect of pre-treatment with gabaculine on oxyfluorfen-induced desiccation and electrolyte leakage from cucumber cotyledons.

Gabaculine treatment was made on root of intact cucumber plant for $15 \mathrm{hr}$ followed by oxyfluorfen (1 $\mu \mathrm{M}$ ) treatment to shoots for $1.5 \mathrm{hr}$ and then exposure to light $\left(150 \mu \mathrm{E} / \mathrm{m}^{2} / \mathrm{S}\right)$. Electrolyte leakage and water content were determined at 6 and $8 \mathrm{hr}$ after light exposure, respectively. Bars represent SD of the mean.

(C: untreated control, G: gabaculine, O : oxyfluorfen) 


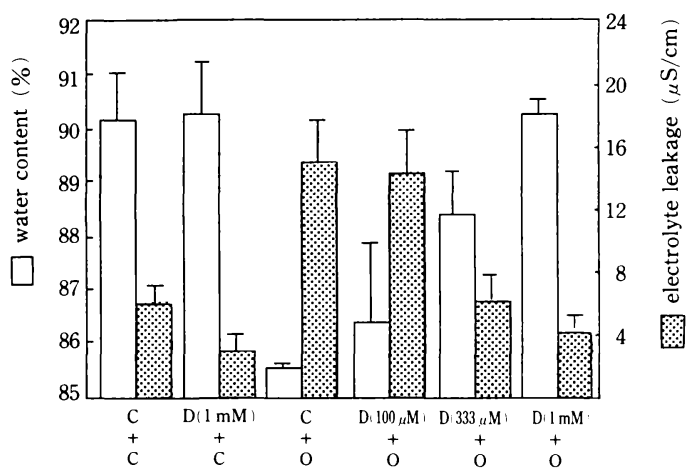

Fig. 2. Effect of pre-treatment with DHA on oxyfluorfen-induced desiccation and electrolyte leakage from cucumber cotyledons.

Experimental conditions are shown in Fig. 1. Bars represent $\mathrm{SD}$ of the mean.

(C: untreated control, D: DHA, O: oxyfluorfen)

respectively. Water content of oxyfluorfentreated plants was reduced drastically within $8 \mathrm{hr}$ and a large quantity of electrolytes leaked from the cotyledons after 6-hr light exposure (Figs. 1 and 2). However, pre-treated tetrapyrrole biosynthesis inhibitors reduced this oxyfluorfeninduced action. Gabaculine (100 $\mu \mathrm{M}-1 \mathrm{mM})$ completely suppressed desiccation and electrolyte leakage (Fig. 1). Increasing concentration of DHA also reduced the herbicidal action and it was completely arrested by $1 \mathrm{mM}$ of DHA treatment (Fig. 2). The two inhibitors themselves showed no phytotoxic effect at the highest concentration used in the experiment.

\section{Effect of tetrapyrrole synthesis inhibitors on PPIX accumulation}

PPIX content in oxyfluorfen treated cucumber cotyledon rose rapidly under light exposure, peaking at $2 \mathrm{hr}$ and then rapidly decreasing (Fig. 3). Only a small accumulation occurred during the 1.5 $\mathrm{hr}$ of oxyfluorfen treatment in darkness. Effect of pre-treated gabaculine or DHA on oxyfluorfen-induced PPIX accumulation was surveyed at $2 \mathrm{hr}$ after the light exposure (Table 1 ). Gabaculine completely suppressed its accumulation at higher than $333 \mu \mathrm{M}$. Increasing concentration of DHA also reduced accumulation of

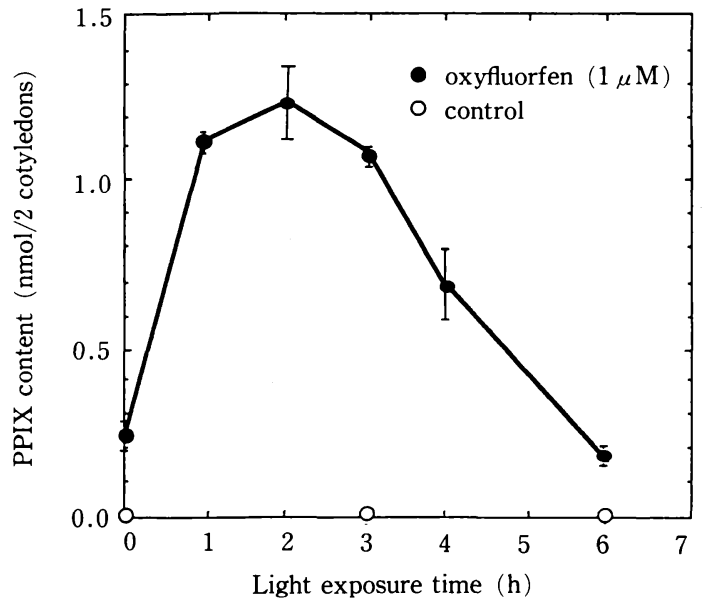

Fig. 3. Time course of accumulation of PPIX in oxyfluorfen-treated cucumber cotyledons during $6 \mathrm{hr}$ of light exposure $\left(150 \mu \mathrm{E} / \mathrm{m}^{2} / \mathrm{s}\right)$.

Shoots of the plant were soaked in oxyfluorfen $(1 \mu \mathrm{M})$ solution for $1.5 \mathrm{hr}$ in darkness and then exposed to light. Bars represent SD of the mean.

Table 1. Effect of pre-treatment with tetrapyrrole synthesis inhibitors on oxyfluorfen-induced PPIX accumulation in cucumber cotyledons*.

\begin{tabular}{|c|c|c|c|c|}
\hline \multirow[b]{3}{*}{ Inhibitor } & \multicolumn{4}{|c|}{ PPIX content $(\mathrm{nmol} / \mathrm{g} \mathrm{FW})^{* *}$} \\
\hline & \multicolumn{4}{|c|}{ Inhibitor concentration } \\
\hline & 0 & $100 \mu \mathrm{M}$ & $333 \mu \mathrm{M}$ & $1 \mathrm{mM}$ \\
\hline \multirow[t]{2}{*}{ gabaculine } & & $0.04 \pm 0.02$ & $<0.02$ & $<0.02$ \\
\hline & $2.60 \pm 0.43$ & & & \\
\hline DHA & & $2.13 \pm 0.33$ & $0.83 \pm 0.14$ & $0.31 \pm 0.10$ \\
\hline
\end{tabular}

* Roots of intact cucumber plants were treated by inhibitors for $15 \mathrm{hr}$ followed by oxyfluorfen $(1 \mu \mathrm{M})$ treatment to shoots for $1.5 \mathrm{hr}$ and then exposure to light $\left(150 \mu \mathrm{E} / \mathrm{m}^{2} / \mathrm{s}\right)$. Cotyledons were sampled after 2-hr light irradiation.

** Values are mean of three replications $\pm \mathrm{SD}$.

PPIX and only a small quantity was accumulated at $1 \mathrm{mM}$.

\section{Discussion}

A diphenyl ether herbicide oxyfluorfen induced light dependent phytotoxic action on intact cucumber seedlings. Water content of the plant decreased rapidly and electrotyle leaked from the 
cotyledons (Figs. 1 and 2). It is considered that membrane disruption and chlorophyll degradation caused by the herbicide are responsible for the bleaching and desiccation.

Gabaculine and DHA are inhibitors of aminotransferase activity which produces $\delta^{-}$ aminolevlinic acid (ALA) from glutamate-1semialdehyde in a five-carbon pathway ${ }^{3,11)}$ and of ALA dehydratase which produces porphobilinogen from $\mathrm{ALA}^{8,22)}$, respectively. Treatment to roots of cucumber plant by inhibitors prior to oxyfluorfen treatment suppressed the herbicidal activity (Figs. 1 and 2). Similar effects have been reported in detached tissues, leaf disks or cultured cells. However, we found that the suppression of diphenyl ether's action by the tetrapyrrole synthesis inhibitors was also present in intact cucumber plant.

A large amount of PPIX was accumulated rapidly in cucumber cotyledons by oxyfluorfen treatment in the light (Fig.3). The amount of PPIX reached the maximum $2 \mathrm{hr}$ after light irradiation and then rapidly decreased. The pattern of PPIX accumulation and dissipation in intact cucumber cotyledons was very similar to that in L.paucicostata ${ }^{20)}$. Photodegradation and metabolism of PPIX in plants have been suggested as one of the main factors of the decrease ${ }^{1,13,20)}$. PPIX accumulation appeared to be enhanced by the light irradiation. Mayer and Beale $^{21)}$ reported that ALA synthesizing enzymes from glutamate were light dependent. Thus, enhancement of ALA synthesis by light may be involved in this high level of PPIX accumulation.

PPIX accumulation during 2-hr light irradiation was almost arrested by any concentration of gabaculine used in the experiment (Fig. 3 and Table 1). Significant decrease by DHA was detected at higher than $333 \mu \mathrm{M}$. This reducing pattern of PPIX accumulation paralleled that of oxyfluorfen activity.

All above data strongly suggest that PPIX is directly involved in the photodynamic herbicial action of oxyfluorfen on intact cucumber plants.

\section{References}

1) Becerril, J.M. and S.O. Duke 1989. Protoporphyrin IX content correlates with activity of photobleaching herbicides. Plant Physiol. 90, 1175-1181.

2) Becerril, J.M. and S.O. Duke 1989. Acifluorfen effects on intermediates of chlorophyll synthesis in green cucumber cotyledon tissues. Pestic. Biochem. Physiol. 35, 119-126.

3) Corriveau, J.L. and S.I. Beale 1986. Influence of gabaculine on growth, chlorophyll synthesis, and $\delta$-aminolevulinic acid synthase activity in Euglena gracilis. Plant Sci. 45, 9-17.

4) Cox, G.C. and D.G. Whitten 1983. Excited state interaction of protoporphyrin IX and related porphyrins with molecular oxygen in solutions and in organized assemblies. In "Porphyrin Photosensitization" (D. Kessel and T.J. Dougherty, Eds.), pp. 279-292, Plenum Press, New York.

5) Derrick, P.M., A.H. Cobb and K.E. Pallett 1988. Ultrastructural effects of the diphenyl ether herbicide acifluorfen and experimental herbicide M \& B 39279. Pestic. Biochem. Physiol. 32, 153-163.

6) Duke, S.O., J. Lydon, and R.N. Paul 1989. Oxadiazon activity is similar to that of $p^{-}$ nitro-diphenyl ether herbicides, Weed Sci. 37, 152-160.

7) Duke, S.O., J.M. Becerril, T.D. Sherman and H. Matsumoto 1990. Photosensitizing porphyrins as herbicides. Am. Chem. Soc., Symp. Ser. No. 449, 371-386.

8) Ebert, P.S., R.A. Hess, B.C. Frykholm and D.E. Tshudy 1979. Succinylacetone, a potent inhibitor of heme biosynthesis: Effect on cell growth, heme content and $\delta$-aminolevulinic acid dehydratase activity of malignant murine erythroleukemia cells. Biochem. Biophys. Res. Commun. 88, 1382-1390.

9) P. Haworth and F.D. Hess 1988. The generation of singlet oxygen $\left({ }^{1} \mathrm{O}_{2}\right)$ by the nitrodiphenyl ether herbicide oxyfluorfen is independent of photosynthesis. Plant Physiol. 86, 672-676.

10) Jacobs, J.M., N.J. Jacobs, S.E. Borotz and M.L. 
Guerinot 1990. Effects of the photobleaching herbicide, acifluorfen-methyl, on protoporphyrinogen oxidation in barley organelles, soybean root mitochondria, soybean root nodules, and bacteria. Arch. Biochem. Biophys. 280, 369375.

11) Kannangara, C.G. and A. Schouboe 1985. Biosynthesis of $\Delta$-amino-levulinate in greening barley leaves. VII. Glutamate 1-semialdehyde accumulation in gabaculine treated leaves. Carlsberg Res. Commun. 50, 179-191.

12) Kenyon, W. H., S. O. Duke and K. C. Vaughn 1985. Sequence of effects of acifluorfen on physiological and ultrastructural parameters in cucumber cotyledon discs. Pestic. Biochem. Physiol. 24, 240-250.

13) Kojima, S., H. Matsumoto and K. Ishizuka 1991. Protoporphyrin IX accumulation in Lemna paucicostata Hegelm. caused by diphenyl ether herbicides and their herbicidal activity. Weed Res., Japan 36, 318-323.

14) Kunert, K.J., C. Homrighausen, H. Bohme and P. Böger 1985. Oxyfluorfen and lipid peroxidation: Protein damage as a phytotoxic consequence. Weed Sci. 33, 766-770.

15) Lydon, J. and S.O. Duke 1988. Porphyrin synthesis is required for photobleaching activity of the $p$-nitrosubstituted diphenyl ether herbicides. Pestic. Biochem. Physiol. 31, 74-83.

16) Matringe, M. and R. Scalla 1988. Effects of acifluorfen-methyl on cucumber cotyledons: Porphyrin accumulation. Pestic. Biochem. Physiol. 32, 164-172.

17) Matringe, M. and R. Scalla 1988. Studies on the mode of action of acifluorfen-methyl in nonchlorophyllous soybean cells. Plant Physiol. 86, 619-622.

18) Matringe, M., J.-M. Camadro, P. Labbe and R.
Scalla 1989. Protoporphyrinogen oxidase as a target for diphenyl ether herbicides. Biochem. J. 260, 231-235.

19) Matringe, M., J.-M.Camadro, P. Labbe and R. Scalla 1989. Protoporphyrinogen inhibition by peroxidizing herbicides: oxadiazon, LS82556 and M \& B 39279. FEBS Lett. 245, 35-38.

20) Matsumoto, H. and S.O. Duke 1990. Acifluorfen-methyl effects on porphyrin synthesis in Lemna paucicostata Hegelm. 6746. J. Agric. Food Chem. 38, 2066-2071.

21) Mayer, S.M. and S.I. Beale 1990. Light regulation of $\delta$-aminolevulinic acid biosynthetic enzymes and tRNA in Euglena gracilis. Plant Physiol. 94, 1365-1375.

22) Meller, E. and M.L. Gassman 1981. Studies with 4,6-dioxoheptanoic acid on etiolated and greening barley leaves. Plant Physiol. 67, 1065-1068.

23) Orr, G.L. and F.D. Hess 1982. Mechanism of action of the diphenyl ether herbicide acifluorfen-methyl in excised cucumber (Cucumis sativus L.) cotyledons. Plant Physiol. 69, 502-507.

24) Sherman, T.D., J.M. Becerril, H. Matsumoto, M.V. Duke, J.M. Jacobs, N.J. Jacobs and S.O. Duke 1991. Physiological basis for differential sensitivities of plant species to protoporphyrinogen oxidase-inhibiting herbicides. Plant Physiol. 97, 280-287.

25) Witkowski, D.A. and B.P. Halling 1988. Accumulation of photodynamic tetrapyrrole induced by acifluorfen-methyl. Plant Physiol. 87, 632637.

26) Witkowski, D.A. and B.P. Halling 1989 . Inhibition of plant protoporphyrinogen oxidase by the herbicide acifluorfen-methyl. Plant Psysiol. 90, 1239-1242. 
キュウリ無傷植物体でのオキシフルオルフェン 活性とプロトポルフィリン IX 蓄積のテトラ ピロール合成阻害剤による抑制

松本 宏*・石塚皓造*

\section{摘 要}

オキシフルオルフェンは光の存在下で, 感受性植 物を短時間内に枯殺する作用をもつ。この殺草作用 発現へのテトラピロール蓄積の関与をより明らかに するために，テトラピロール合成阻害剤を前処理し たキュウリ無傷植物に対するオキシフルオルフェン の作用と,プロトポルフィリン IX の蓄積への影響 を調べた。

キュウリの茎葉部を暗条件下で $1 \mu \mathrm{M}$ のオキシフ ルオルフェンに 1.5 時間浸漬した後に光 (150 $\left.\mu \mathrm{Em}^{-2} \mathrm{~s}^{-1}\right)$ を照射すると，茎葉部に速やかな白化と 乾燥がおこった。テトラピロール合成阻害剤である

*筑波大学応用生物化学系 gabaculine と 4,6-dioxoheptanoic acidをオキシ フルオルフェンの処理前 15 時間にわたって根から 吸収させると，それぞれ $0.1 \mathrm{mM}$ と $1 \mathrm{mM}$ の濃度で オキシフルオルフェンの作用をほぼ完全に抑制した (Fig. 1, Fig. 2)。これらの前処理をせずにオキシフ ルオルフェンのみを処理したキュウリ体内には, 可 視症状の発現に先んじて急激なプロトポルフィリン IX の蓄積がおこり, 蓄積量は光照射後 2 時間でピー クに達した（Fig. 3)。阻害剂を前処理した場合はプ ロトボルフィリンIX の蓄積が抑制され, 蓄積と作 用の抑制の程度はよく一致した (Table 1)。

これらのことからキュウリの無傷植物体でおこる オキシフルオルフェンの枯殺作用に，それによって 蓄積されるプロトポルフィリンIXが直接に関与し ているものと考兄られた。

キーワード:オキシフルオルフェン，プロトポル フィリン IX, gabaculine, 4, 6-dioxoheptanoic acid, 作用機構 